\title{
Aspects of political theology in Thomas Merton's spiritual autobiography
}

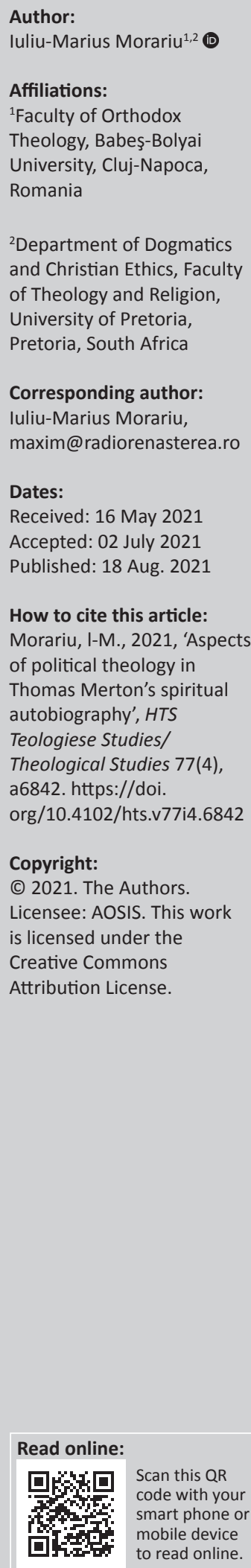

An important personality of the Catholic space of the 20th century and, at the same time, of the ecumenical and the inter-religious, Thomas Merton (1915-1968) is one of the most important authors of spiritual autobiographies in the Christian space. Knowing this and the fact that from other points of view, his work has been investigated by different researchers from all around the world, we will try to present the aspects of the political theology which can be found in works such as: The Seven Storey Mountain (1948), The Sign of Jonas (1953), among others, which he wrote and which contain passages of spiritual autobiographies. These works emphasise aspects such as his attitude towards racism (a problem which he encountered in the America of the 1960s), war or Communism (because of the fact that before he studied at Columbia University, but also during this period, he also sympathised with the Communists). The author will therefore try to present some practical aspects of his works, and show how they can be used to create bridges between society and church; the answer he gives to the challenges of his time.

Contribution: The article presents the main aspects of political theology which can be found in Merton's work and shows how keywords such as war, racism or Communism have been seen by him and the views he has of a potential attitude of the Church towards them.

Keywords: Thomas Merton; political theology; spiritual autobiography; War; Communism.

\section{Introduction}

It is difficult to write about Thomas Merton. His writings have been printed and re-printed over the years, and even the exotic aspects such as his ecological conviction (Jensen 2020:7-8), racism (Feurherd 2021:5-6; Horan 2020:7-18), his openness towards Buddhism (Di Valerio 2020:474-475) or his humour (Pearson 2020:221-242), have all been investigated. However, there are certain aspects of his life as the Trappist monk (having had a vocation as a writer, yet living the life of a monk, was one of Merton's great struggles in life, especially in his early years in the monastery), that still should be investigated; and they could undoubtedly say many things to the contemporary reader.

As discovered over the past years, through his notes, Merton was close to political theology and to the presence of this aspect in his spiritual autobiographies (Kalaitzidis 2012; Losonczi, LuomaAho \& Singh 2011; Morariu 2018a:153-157, 2018b, 2018c, 2019a, 2020:1-5; ed. Ricci 2012; Stoeckl, Gabriel \& Papanikolau 2017). We will try in this research to present the way in which this topic interferes with his spiritual autobiography.

Before proceeding further, a few clarifications are necessary. It would have certainly been useful to be able provide a presentation of his life and activities analysed previously to this investigation in order to help the reader to have a deeper understanding of his life. However, because of the scope of this research, this is not possible. The reader/s who however, want to learn more about this topic can refer to recent publications such as: Pearson (2020:221-242), Morariu (2021:183-184), as also the various publications indicated below.

When talking about spiritual autobiographies, one may be tempted to think that there is one book belonging to this genre in the entire work of an author. In many cases, this is indeed the reality (see e.g. Morariu 2019b:233, 2019c:310). In the case of Merton (1915-1968), a man who converted to Christianism after having previously been a convinced Communist and who wrote 50 books in 27 years, until an unpredicted electrocution ended his earthly journey (Di Valerio 2020:473-474), the situation is different. All his books, including The Seven Storey Mountain (Merton 1948), which marks his moment of beginning, The Sign of Jonah (Merton 
1953), his poetical works (Merton 1957, 1959, 1963a, 1968, 1969, 1985, 2005), or his letters (Merton 1993, 1994), contain at least some passages of spiritual autobiography. His road to Salvation and his dialogue with divinity, an essential element of any work belonging to this genre (Morariu 2018d:145), can be found in each of them. For this reason, we will resort to all his works, extracting the main aspects related to his political theology, which can be found there. From The Seven Storey Mountain for example, we will extract and analyse his ideas about Communism, while in others we will try to emphasise his conception of topics such as war (particularly the Second World War and the Vietnam war), racism or the way in which the Church should regard and work with these aspects. When necessary, we will compare his conception with one of the other relevant authors from the same area, in order to recognise the influences and to emphasise the topical nature of some of his ideas.

\section{Aspects of political theology in Thomas Merton's spiritual autobiography}

\section{Thomas Merton and War}

A topic often approached by the investigated author and which is linked to his political theology is certainly war. Sometimes, war inspires him to write poetical texts ${ }^{1}$ or letters, but, at the same time, to remain a pacifist, therefore remaining faithful to his Church (ed. Carlen Ihm 1981:74). Among his notes, there is a very interesting one about the 'just war', which later became a topic intensely discussed by the Popes (Carneiro 2016:205-220) and also by other Christians. Merton (1948) underlined the fact that:

For a war to be just, it must be a war of defence. A war of aggression is not just. If America entered the war now, would it be a war of aggression? I suppose if you wanted to get subtle about it, you could work out some of an argument to that effect. But I personally could not see that it would be anything else that legitimates self-defence. (311)

As a pacifist, ${ }^{2}$ he was clearly a militant one - a man who just hated war. Moreover, he tried to converse with those who wanted war and to convince them that they were on the wrong track. For him, just like for other American pacifists, Cold War represented a context which allowed him to act. Although it failed the 'Lincoln call', ${ }^{3}$ but was an important

1.'Meanwhile, suddenly, one day, towards the beginning of the Lent, i began to write poems. I cannot assign any special cause for the ideas that began to crowd on me from every side. I had been reading the Spanish poet, Lorca, with whose poetic vein I felt in the greatest sympathy: but it was not enough, in itself, to account for all the things I now began to write' (Merton 1948:310)

2.In the beginning of the Second World War, he noted: 'All I could see was a world in which everybody said they hated war, and in which we were all being rushed into a war with a momentum that was at last getting dizzy enough to affect my stomach (Merton 1948:214).

3.'In 1861, a month before the outbreak of the Civil War, Abraham Lincoln implored Americans, North and South, to act on the "better angels of our nature." In 1961, in the sixteenth year of the forty-five-year Cold War, Thomas Merton invited friend and strangers to cast out Americas foulest demons. Lincolns appeal faled. The angels didn't appear. War broke out. Merton's writings had no measurable impact on the nuclear arms race, the Cold War, or foreign or domestic policy, then or since. And the evils he describes so impeccably still thrive' (Commins 2020:55). attempt to call for peace. According to him, God's love was the strongest argument for peace. ${ }^{4}$ If God loves all the people and can forgive all their sins, people should also be able to love their neighbours. ${ }^{5}$

Merton's bravery and his fidelity to peace were strongly tested during this period. His order censored him and, therefore, he was forced, just like the ones who investigated his biography, to be inventive and re-invent himself in order to keep his militant attitude, and to be faithful to his principles:

Merton wrote the Cold War Letters because in 1961-1962, the year leading up to and through the Cuban Missile Crisis, his Cistercian Order had silenced him. To his superiors, writing on war was not a suitably pious pursuit for a monk. Told to keep quiet, Merton bristled. He waffled. He obeyed outwardly; he appealed the censure; he skirted the directive as he impishly published political articles under zany aliases like 'Benedict Monk'. With the Cold War Letters, he tested an alternative strategy. Because the censorship didn't ban opinions on war from his personal correspondence, he would collect some of his private letters and - using Sixties' technology - have them mimeographed, bound, and privately distributed. (Commins 2020:59)

In this context, he made a rich contribution to the work of war condemnation and remained a pacifist whose voice had something important to say in a crucial moment of history. The demonic nature of the times he lived in (Coming 2020:59) could look rather exaggerated for the readers, but it was a strong accent, well put, whose aim was to determinate the world to understand the complexity of the situation they were living. The same context was used by him in order to condemn the American self-perception of being a paradise and its illusion of spreading peace and a superior model of life. As Commins (2020) showed in his analysis:

The 'American mentality', as he calls it, 'is involved in deep illusions, most of all about itself - The illusion of America as the earthly paradise, in which everyone recovers original goodness: which becomes in fact a curious idea that prosperity itself justifies everything, is a sign of goodness, is a carte blanche to continue to be prosperous in any way feasible'. Because of this wealth, 'we are entitled to defend ourselves by any means whatever, without any limitation, and all the more so because what we are defending is our illusion of innocence' (Merton 1961:179). The ideology that spurred the arms race not only justified (and sanctified) itself; its gravitational pull absorbed all other belief systems into its black hole. (p. 60)

Without being a critic of his land, as Chomsky (2020) is nowadays, Merton understood the situation of his contemporary society and tried to fight against some of its potential outcomes. His road back from England, where he

4.'For it is God's love that warms me in the sun and God's love that sends the cold rain. It is God's love that feeds me in the bread I eat and God that feeds me also by hunger and fasting' (Merton 1961:16).

5.Starting from this assumption, he developed a complex system of thinking with Christian fundamentals: 'Merton condemns America's violent mindset as the antithesis of the mind of Christ (Phlp 2:5-11). The belief system that undergirds the arms race is not only anti-Christian. It is built on a house of bizarre syllogisms. Military and political leaders' "hard-nosed and stiff-necked way of missile rattling Military and political leaders' "hard-nosed and stiff-necked way of missile rattling
and nuclear threats" reveals "a mentality that is insensitive to the realities of and nuclear threats" reveals "a
nuclear war"' (Commins 2020:59). 
studied before the Second World War, made him get in contact with different realities and his travels, while being a student at Columbia University, even allowed him to observe in certain situations the Nazi spies ${ }^{6}$ and, therefore, to understand war from the outside, and to become a peace militant. The religious transformation he went through while becoming a Trappist monk and his interactions with other people who preached peace, namely Buddhists, definitely influenced his way of thinking. At the same time, he was also aware of the fact that he was only an individual, which transformed him into someone without an authority, ${ }^{7}$ But he understood that if more individuals unite their forces, they can change the world.

\section{Thomas Merton and Communism}

It is still a mystery how a man with such a deep mystical predilection, influenced by important Christian personalities such as Teresa of Avilla and John of the Cross (Hole 2020:47; eds. Shannon et al. 2002:470), could be for a while a Communist. This adherence and the experiences it generated, which are described in detail in The Seven Storey Mountain, are complex and deserve an analysis as to the aspects which determined it.

An assumption which defined Merton's (1948) thought before his conversion is the one according to which man is the product of the society in which he lives:

It is true that the materialistic society, the so-called culture that has evolved under the tender mercies of capitalism, has produced what seems to be the ultimate limit of this worldliness. And nowhere, except perhaps in the analogous society of pagan Rome, has there even been such a flowering of cheap and petty and disgusting lusts and vanities as in the world of capitalism, where there is no evil that is not fostered and encouraged for the sake of making money. We live in a society whose whole policy is to excite every nerve in the human body and keep it at the highest pitch to create as many new desires and synthetic passions as possible, in order to cater to them with the products of our factories and printing presses and movie studios and all the rest. (p. 133)

This idea is not a new one and it was also expressed by the founders of Communism as an ideology (Marx 1947). There are many other such ideas. Looking in the past, after the moment of his conversion, Merton realised that his being close to this way of living was related more to the attempt of finding someone guilty for his way of living and of his situation. In other words, according to him, this period was one when he searched to blame the society in which he lived for his unhappiness, instead of blaming himself and his way

6.'But when September came I sailed for England once more. This time I made the crossing of the Manhattan, a garish and turbulent cabin class steamer full of Nazi spies working as stewards and detesting the Jewish passengers' (Merton 1948:118).

7.I knew that I myself hated war, and all the motives that led to war and were behind wars. But I could see that now my likes or dislikes, beliefs or disbeliefs meant absolutely nothing in the external political order. I was just an individual, and the individual had ceased to count. I meant nothing, in this world, except that I would probably soon become a number on the list of those to be drafted. I would get a piece of metal with my number on it, to hang around my neck, so as to help out the circulation of red-tape that would necessarily follow the disposal of my remains, circulation of red-tape that would necessarily follow the disposal of my remains, and that would be the last eddy
identity' (Merton 1948:214). of living, thinking and acting for the way in which things were evolving. ${ }^{8}$

The classical propaganda machine used by the Communists from the Russian space managed to attract him more than the American one, which was clearly better equipped at the level of design and marketing. It is interesting that it was not Columbia University, known for its predilection towards this direction and for the affinity of a certain category of professors for the left-wing, ${ }^{9}$ but Strasbourg which brought him closer to this ideology, as he later confessed in his spiritual autobiography:

It was some four years since I had first read the Communist Manifesto and I had never entirely forgotten about it. One of those Christmas vacations at Strasbourg I had read some books about Soviet Russia, how all the factories were working overtime, and all the ex-moujiks wore great big smiles on their faces, welcoming Russian aviators on their return from Polar flights, bearing the boughs of threes in their hands. Then I often went to Russian movies, which were pretty good from the technical point of view, although probably not so good as I thought they were, in my great anxiety to approve of them.

Finally, I had in my mind the myth that Soviet Russia was the friend of all the arts, and the only place where true art could find a fringe in a world of bourgeois ugliness. Where I ever got that idea is hard to find out, and how I managed to cling to it for so long is harder still. (Merton 1948:132)

Later, when he no longer felt attracted by the Communists, this experience became useful for the French monks living in an American abbey. He could understand the ones who were seeing bourgeois elements in the way the Church acted of the Church, ${ }^{10}$ and considered perfection to be the only solution to this problem. Moreover, he was able to characterise the way in which the bourgeoisie had impacted on Christianity, showing that:

The impact of the bourgeoisie on Christianity had the same characteristic elements as its impact on any other aspect of life. It has produced a huge network of escapes and substitutes that extends to the margins of Christianity. It fails to undermine its essential core because the world cannot touch the heart of the

8.'So now, when the time came for me to take spiritual stock of myself, it was natural that I should do so by projecting my whole spiritual condition into the sphere of that was that it was not so much I myself that was to blame for my unhappiness, but the society in which I lived' (Merton 1948:131132).

9.In fact, when speaking about the university from which he graduated, Thomas Merton himself insists on the fact that, there, Communism was an ideology people Merton himself insists on the fact that, there, Communism was an ideology people
often adhered to and there was a common legend in New York, according to which often adhered to and there was a common legend in New York, according to which this space was almost entirely a Communist feud: 'There was a sort of a legend in
New York, fostered by the Hearst papers, that Columbia was a hotbed of New York, fostered by the Hearst papers, that Columbia was a hotbed of
Communists. All the professors and students were supposed to be Reds, except perhaps the president of the university, Nicholas Murray Butler' (Merton 1948:141)

10.'It is one of the apparent misfortunes of the church of our century, that of having been almost identified, in the minds of some, with the middle class, as if the interests of the church coincide with those of the bourgeoisie. However, this identification is impossible, because opposites cannot coincide. It would be like saying that Christ casts out demons through Beelzebub, the prince of demons. Since than prince of demons Since many Catholics, however, actually live an existence that practically makes these two opposites coincide in them, among the worst enemies of Christ the ide prevails that Catholicism is really nothing more than a facade for the bourgeoisie. There is no answer to this argument other than the practical one, of Christian perfection: health. The goodness of the tree can be seen from the fruits, and what many of us seem to forget and that the Communists have the right to expect that we show fruits worthy of Christ's teaching' (Merton 2018:67). 
church. Certainly, however, it can contaminate what covers it. (Merton 1948:67-68)

His being close to Communism determined him to blame Capitalism for all the sins of the world, just like others had done previously or would do after him. Or even caused the imminence of revolutionary actions and the revolutions themselves. ${ }^{11}$ His utopian version, which speaks about general happiness and the progress of society in a direction which would help everyone improve their standard of living without being overworked (Merton 1948:134), was therefore accomplished. Later on, when he ceased to be a Communist, Merton characterised himself and his options as being based on a lack of logic and showed that his choice of the jargon which came with it, transformed him into a good Columbia Man (Merton 1948:138):

The thing that made Communism seem to be plausible to me was my own lack of logic which failed to distinguish between the reality of the evils which Communism was trying to overcome and the validity of its diagnosis and the chosen cure. (p. 135) 12

In this vision, God was an invention of the ruling classes, used in order to dominate the others (Merton 1948:146), and stability, harmony and order were the pillars (Merton 1948:145-146). As Merton confesses, he was also active as a Communist militant while taking part in a manifestation of the Columbia Communists. ${ }^{13}$

What he later saw at a practical level helped him understand that real life is different from theory in the Communist space and this made him give up his sympathy for this cause. At the same time, it also helped him identify certain aspects and influences this area had in the Christian space and, when it was possible, he tried to speak about them, in order to determine Christians to give up these influences.

\section{Thomas Merton and Racism}

Another aspect which brings Thomas Merton close to political theology and which is also part of his militant attitude is his conception about racism. Already investigated by the writers who wanted to find more about his life and activity (Feurherd 2021:5-6; Horan 2020:7-18), it is something which became topical again in 2020, in the context of the political and social events of the United States of America.

\footnotetext{
11.It was capitalism that was to blame for everything unpleasant, even the violence of the revolution itself. Now, of course, the revolution had already taken the first successful step in Russia. The Dictatorship of the Proletariat was already set up successful step in Russia. The Dictatorship of the Proletariat was already set up there. It would have to spread through the rest of the world before it could be said that the revolution had really been a success. But once it had, once capitalism had
been completely overthrown, the semi-state or Dictatorship of the Proletariat, been completely overthrown, the semi-state or Dictators
would itself only be temporary matter' (Merton 1948:134).

12.As he confesses, the idealisation of Communism was what made him have this option: 'I had formed a kind of an ideal picture of Communism in my mind, and now I found that the reality was a disappointment ...I had thought that Communists were calm, strong, definite people, with very clear ideas as to what was wrong with everything' (Merton 1948:146). Later on, his interactions with the real life which this way of living generated, made him change his mind.

13.'My active part in the world revolution was not very momentous. It lasted, in all, about three months. I picketed the Casa Italiana, I went to the Peace Strike, and I think I made some kind of a speech in the big classroom on the second floor of the Business School, where the N.S.L. had their meetings. Maybe it was a speech on Business School, where the N.S.L. had their meetings. Maybe it was a speech on
Communism in England - a topic about which I knew absolutely nothing' (Merton 1948:147).
}

When speaking about him and this behaviour, there are a few things which should be clearly emphasised. One is the fact that he defined himself as a 'white liberal', as it can be seen from a study he published, where he tackled the topic (Merton 1963b:464-477) and whose bibliography include black thinkers:

Merton took the time to actually read Black thinkers and writers. And not just the ones that make white people comfortable. He read Malcolm X. And Martin Luther King. And James Baldwin. He read them not to refute their arguments, but to be informed by them. He read them with an openness to being seared by what they had to say, with an openness to being converted to new ways of thinking and acting. (Feurherd 2021:6)

References from his books (Merton 1976:10) prove this aspect, together with his prophetical qualities (Horan 2020:71) ${ }^{14}$ and with the fact that he claimed that the Church could not remain without any reaction to such an important problem. ${ }^{15}$ As one of his contemporary exegetics shows, his letters which fight against racism come as a reaction to Martin Luther King's 'Letter from Birmingham Jail'16 and touch upon a sensitive aspect, speaking about the need for education and for social actions meant to change a certain mentality that was often encountered in the American society of his time.

\section{Conclusion}

Did Mertons succeed in creating bridges between the society and church? As we have tried to show here, Yes. He showed both to his superiors that the church should be implied in the social life and showed to the society, through his books, attitudes and work, that the aforementioned institution is interested in topics like the political theology and could offer solutions. Also, in many situations, he provided solutions to the challenges of his time, by questioning himself and the others, and finding ways to overcome the crisis that appeared then. Merton, therefore, shows how theology and religion can influence the political way of thinking, both in a practical and theoretical way (as others like Dag Hammarskjold or Mother Teresa of Calcutta did). To the racism, the religion and theology oppose, as he emphasises topics like the love for the neighbour and the equality between people. To the war, the quest for peace, and so on.

Coming from a religious perspective, the notes of political theology which can be identified in Thomas Merton's spiritual autobiography are important and can contribute, on

14. There is a lot in Merton's writings on racism that is laudable and reflects a truly prophetic quality particularly when we view his social location and historical prophetic quality, particularly when we view his social location and historical context: he was a white, Euro-American male, renowned author, ordained Catholic
priest and cloistered monk set somewhat apart from the world in the bluegrass hillside of rural Kentucky during the 1940s, '50s and '60s' (Horan 2020:71).

15.'For Merton, this phenomenon of systemic racism as part and parcel of American culture is not limited to the sphere of civil politics or social norms, but also implicates the Catholic Church and Christianity rite, large in the United States' (Horan 2020:72).

16.'The most well-known and well-read of Merton's anti-racist writings is his essay "Letters to a White Liberal." Written in 1963 in response to Martin Luther King's "Letter from Birmingham Jail," this lengthy reflection on the nature of anti-black racism in the United States is presented as Merton's attempt to listen, process and integrate what he is hearing and reading about the quest for racial justice, especially from the perspective of black authors and civil rights leaders. In the conclusion of the essay, Merton explains that his aim was as introspective as it was conclusion of the essay, Merton explains that his aim was as introspective as it was
exhortatory, stating plainly that what is necessary for white people is that they actually listen to their black sisters and brothers' (Horan 2020:72). 
the one hand, to the understanding of the need of communication between the theological and religious space and the political area and, on the other, to the idea that Christianity is called to militate against certain behaviours which could be encouraged by the political space. Communism, war and racism are the keywords of his notes. His encounter with them in different forms and contexts helped Merton define himself and progress on the road towards meeting God. At the same time, it gave him a deeper understanding of the world and society, making him love his neighbour and develop practical ways of getting involved in the development of society and the achievement of common good. For this very reason, his spiritual autobiography must also be regarded from this point of view, analysing the practical accents he puts.

\section{Acknowledgements Competing interests}

The author declares that he has no financial or personal relationships that may have inappropriately influenced him in writing this article.

\section{Author's contributions}

I-M.M. is the sole author of this article.

\section{Ethical considerations}

This article followed all ethical standards for research without direct contact with human or animal subjects.

\section{Funding information}

This research received no specific grant from any funding agency in the public, commercial or not-for-profit sectors.

\section{Data availability}

Data sharing is not applicable to this article as no new data were created or analysed in this study.

\section{Disclaimer}

The views and opinions expressed in this article are those of the author and do not necessarily reflect the official policy or position of any affiliated agency of the author.

\section{References}

Carlen Ihm, C. (ed.), 1981, The Papal Encyclical (1903-1939), The Pierian Press, Raleigh, NC.

Carneiro, P.E., 2016, 'Just War tradition and the Popes: From Pius $\mathrm{X}$ to Francis', RevistaBrasileira de Estudos de Defesa 3(1), 205-220. https://doi.org/10.26792/ rbed.v3n1.2016.61708

Chomsky, N., 2020, How the world Goes, CurteaVeche Publishing, Bucharest.
Di Valerio, D., 2020, 'Thomas Merton's encounter with Buddhism and beyond: His interreligious dialogue, inter-monastic exchanges, and their legacy by JaechanAnselmo Park (review)', Buddhist-Christian Studies 40(1), 472-475. https://doi.org/10.1353/bcs.2020.0028

Feurherd, P., 2021, 'Thomas Merton's writings on race still resonate: "Letters to a White Liberal" gains renewed attention in 2020', National Catholic Reporter 57(7), 5-6.

Hole, S., 2020, John of the cross: Desire, transformation, and selfhood, Oxford University Press, Oxford.

Horan, D.P., 2020, 'Racism is a White problem: Thomas Merton, Whiteness and Racial Justice', Merton Annual 33(33), 63-82.

Jensen, E., 2020, 'Ecological conversion and the spiritual exercises', Way 59(2), 7-18.

Kalaitzidis, P., 2012, Orthodoxy \& political theology, World Council of Churches Publications, Geneva.

Losonczi, P., Luoma-Aho, M. \& Singh, A. (eds.), 2011, The future of political theology. Religious and theological perspectives, Ashgate: Farnham, Burlington.

Marx, K., 1947, The capital, Press of the Romanian Communist Party, Bucharest.

Merton, T., 1948, The seven storey mountain, Hardcourt, Brace and Company, New York, NY.

Merton, T., 1953, The sign of Jonas, Hardcourt, Brace and Company, New York, NY.

Merton, T., 1957, The strange Islands, New Directions, New York, NY.

Merton, T., 1959, Selected poems, New Directions, New York, NY.

Merton, T., 1961, New seeds of contemplation, New Directions, New York, NY.

Merton, T., 1963a, Emblems of a season of Fury, New Directions, New York, NY.

Merton, T., 1963b, 'Letters to a White Liberal', Blackfriars 44(521), 464-477. https:// doi.org/10.1111/j.1741-2005.1963.tb00947.x

Merton, T., 1968, Cables to the Ace, New Directions, New York, NY.

Merton, T., 1969, The geography of Lograire, New Directions, New York, NY.

Merton, T., 1976, Ishi means man: Essays on native Americans, Unicorn Press, Greensboro, NC.

Merton, T., 1985, Eighteen poems, New Directions, New York, NY.

Merthon, T., 1993, The courage of truth. The Letters of Thomas Merton to Writers, Farrar, Straus, Giroux, New York, NY.

Merton, T., 1994, Witness to freedom. The letters of Thomas Merton in times of crisis, Farrar, Straus, Giroux, New York, NY.

Merton, T., 2005, In the Dark before Dawn: New selected poems, New Directions, New York, NY.

Merton, T., 2018, Il primatodell a contemplazione. Scritti Inediti, Editrice Missionaria Italiana, Verona.

Morariu, I.-M., 2018a, 'An Orthodox perspective on political theology', Journal for the Study of Religions and Ideologies 17(49), 153-157.

Morariu, I.-M., 2018b, 'Aspects of political theology in the spiritual autobiography of Dag Hammarskjöld', HTS Teologiese Studies/Theological Studies 74(4), a4857, 1-5. https://doi.org/10.4102/hts.v74i4.4857

Morariu, I.-M., 2018c, 'Aspects of political theology in the spiritual autobiography of Saint John of Kronstadt (1829-1908)', HTS Teologiese Studies/Theological Studies 74(4), a4993, 1-5. https://doi.org/10.4102/hts.v74i4.4993

Morariu, I.-M., 2018d, 'An interdisciplinary genre in the theological literature: The spiritual autobiography and its landmarks for the Orthodox space', Journal of Education, Culture and Society 8(1), 145-150. https://doi.org/10.15503/ jecs20181.145.150

Morariu, I.-M., 2019a, 'Aspects of political theology in the spiritual autobiography of Nicolas Berdiaev', HTS Teologiese Studies/Theological Studies 75(4), a5316, 1-4. https://doi.org/10.4102/hts.v75i4.5316

Morariu, I.-M., 2019b, 'Saint FaustinaKowalska and Saint Teresa of Calcutta - Two authors of spiritual autobiographies from Catholic space of the 20th century', Astra Salvensis VII(13), 231-239.

Morariu, I.-M., 2019c, 'Educational aspects in the spiritual autobiography of Mother Teresa of Calcutta', Astra Salvensis VII(14), 307-312.

Morariu, I.-M., 2020, 'Aspects of political theology in the spiritual autobiography of Mother Teresa of Calcutta', HTS Teologiese Studies/Theological Studies 76(1), a5932, 1-5. https://doi.org/10.4102/hts.v76i1.5932

Morariu, I.-M., 2021, 'The Peace as a leitmotiv of the spiritual autobiographies of Thomas Merton and Saint Silouan the Athonite', Astra Salvensis 9(17), 183-189.

Pearson, P.M., 2020, 'Wearing our mitres to bed: Thomas Merton and the need for humor in "This Mad Place",' Merton Annual 33(33), 221-242.

Ricci, G.R. (ed.), 2012, Politics in theology, Transaction Publishers, New Brunswick.

Shannon, W.H., Bochen, C.M. \& O'Connell, P.F. (eds.), 2002, The Thomas Merton encyclopedia, Orbis Books, Maryknoll, NY.

Stoeckl, K., Gabriel, I. \& Papanikolau, A. (eds.), 2017, Political theologies in Orthodox Christianity. Common challenges - Divergent positions, T\&T Clark and Bloomberg, Edinburgh. 